\title{
METHODOLOGICAL ASPECTS OF RISK MANAGEMENT IN ROAD TRANSPORT
}

\section{METODOLOGICZNE ASPEKTY ZARZACDZANIA RYZYKIEM W TRANSPORCIE DROGOWYM}

\author{
Andrzej Szymanek \\ Uniwersytet Technologiczno-Humanistyczny w Radomiu \\ email: a.szymanek@uthrad.pl
}

\begin{abstract}
Safe functioning of transport systems depends on the effective management of safety, which is "management by objectives", i.e. the kind of management system. Its basic principle is: "we manage safety" by "risk management". The need to describe this problem was the main motivation to write an article. A reminder of the central place of road transport on the "map of transport safety researches"- was second motivation to write this article.
\end{abstract}

Keywords: risk management, road risk, road safety

Streszczenie: Bezpieczne funkcjonowanie systemów transportowych zależy od skutecznego zarządzania bezpieczeństwem, które jest „zarzadzaniem przez cele”, czyli rodzajem zarzadzania systemowego. Jego podstawowa zasada brzmi: „zarzadza się bezpieczeństwem” poprzez „zarzadzanie ryzykiem”. Potrzeba opisania tego problemu byta główna motywacja napisania artykułu. Przypomnienie centralnego miejsca transportu drogowego na „mapie badań bezpieczeństwa transportu”- było druga motywacją napisania tego artykulu.

Slowa kluczowe: zarzadzanie ryzykiem, ryzyko drogowe, bezpieczeństwo drogowe 
Methodological aspects of risk management in road transport

Metodologiczne aspekty zarzadzania ryzykiem $w$ transporcie drogowym

\section{Introduction}

The proper functioning of transport systems depends to a large degree on efficient management. It should cause the transport was highly functional, pro-ecologic, economically optimal and, above all, safe. Effective management of safety is management by objectives, i.e. the kind of management system, which basic principle is: "we manage safety" by "risk management". Need a reminder of this topic was the first motivation to write this paper.

There are worked out a variety of organizational, technological and transport systems management standards; mainly air and rail. Meanwhile, the road transport generates the greatest social costs, including the costs of road accidents, the costs of environmental degradation and the congestion costs. One of the four main objectives of the management of road transport is the desire to minimize the number of road accidents, in particular limiting the number of heavy accidents. And these are the problems of road safety management. It is necessary here the system approach [1]. A reminder of the central place of road transport on the "map of transport safety researches"- was second motivation to write this article.

\section{Short introduction to risk management in the technology}

What does it mean: manage risk? Here's one answer: manage the risks, it is getting to know - understanding - learning how to avoid the undesirable events and so alternately acting throughout the life cycle of managed object (system, process, organization). What does it mean: minimize risk? It means: maximize resource of knowledge of probabilities and the effects of potential adverse events (situations) on the managed system.

Risk as an object of research is multi-aspected, multi-faceted. However, his form independently, the levels of risk management and owners can consider three sensible and logical questions:

1) How to assess the risk of possible risks in considered system?

2) What range of the risk may be accepted?

3) How acceptable the scope of risk can be achieved in the light of social and economic factors?

The answer to the first question is risk analysis, to the second risk evaluation, and third risk control. Together they consist on risk management and it is probably one of the simpler definition. It can be found for example in the a Joint Standards Australia/Standards New Zealand Committee OB-007, [2]. This Standard so interpret risk management:"(...) is the term applied to a logical and systematic method of communicating, establishing the context, identifying, analyzing, evaluating, treating and monitoring risks associated with an activity, function or process in a way that will enable organizations to minimize losses and maximize opportunities ". 
Iterative process of risk management includes seven of the following main elements:

1) to communicate and consult; 2) will need the context; 3 ) identify risks (hazardssources of risk, accident scenarios; exposures); 4) analyze risks; 5) evaluate risks; 6) treat risks; 7) monitor and review.

Similar, but even broader is the definition of risk management according to standard ISO 73: “(...) coordinated activities to direct and control an organization with regard to risk. Risk management generally includes risk assessment, risk treatment, risk acceptance and risk communication". This definition refers to an integrated risk management, [3]. Risk management process can be noted conventionally:

risk management

- risk assessment

- risk analysis

- sourced

identification

- risk estimation

- risk evaluation

- risk treatment

- risk avoidance

- risk transfer

- risk reduction

- risk mitigation

- risk retention

- risk optimization

- residual risk

risk acceptance

risk financing

risk control

risk communication

- risk perceptron

- stakeholder

Fig. 1 Risk management process, (self-made on the basis [3]) 
Methodological aspects of risk management in road transport

Metodologiczne aspekty zarzadzania ryzykiem $w$ transporcie drogowym

\section{International standards for risk management. Implementations for the road transport}

Standard ISO 73 also gives definitions for all phases of risk management:

- Risk assessment - overall process of risk analysis and risk evaluation.

- Risk analysis - systematic use of information to identify sources and to estimate the risk. Risk analysis forms the basis for risk evaluation, risk treatment and risk acceptance. Information can include historical data, theoretical analysis, informed opinions and the concerns of stakeholders.

- Risk evaluation - process of comparing the estimated risk.

- Risk avoidance - decision not to become involved in, or action to withdraw from, a risk situation.

- Risk transfer - sharing with another party the burden of loss or benefit or gain, for a risk. Legal, mandatory or statutory rights can limit, prohibit or mandate the transfer of certain risk. Risk transfer can be carried out through insurance or other agreements. Risk transfer can create new risks or modify existing risk.

- Risk reduction - actions taken to lessen the probability, negative consequence, or both, associated with a risk.

- Risk mitigation - limitation of any negative consequence of a particular event.

- Risk retention - the acceptance of the burden of loss or benefit or gain, for a risk.

- Risk optimization - process, related to risk, to minimize the negative and maximize the positive consequences and their respective probabilities.

- Risk acceptance - decision to accept a risk; risk acceptance and risk retention are not the same. Risk retention is a consequence of risk acceptance of a certain risk.

- Risk financing - provision of funds to meet the cost of implementing risk treatment and related costs.

- Risk control - actions implementing risk management.

- Risk communication - exchange or sharing of information about risk between the stakeholders.

Here are a few international standards on which there are items useful to develop a framework methodology and standards for the integrated management of the risk in transport, [4].

ISO 31000:2009. "Risk Management - Principles and Guidelines"; related standards: ISO Guide 73:2009 - Risk Management - Vocabulary; ISO/IEC 31010:2009, Risk management - Risk assessment techniques.

ISO 13824:2009 Bases for design of structures -- General principles on risk assessment of systems involving structures.

ISO 12353-1:2002 Road vehicles -- Traffic accident analysis -- Part 1: Vocabulary; also: ISO 12353-2:2003

ISO/FDIS 26262-1 Road vehicles -- Functional safety -- Part 1: Vocabulary.

Among these standards ISO 31000: 2009 is the most promising in terms of possible transport implementations. 
It is the first as a consistent standard for risk management. Conceived by his creators it have to provide universal principles and guidelines for risk management. ISO 39001:2012 specifies requirements for a road traffic safety (RTS) management system to enable an organization that interacts with the road traffic system to reduce death and serious injuries related to road traffic crashes which it can influence, [5].

\section{The evolution of views on the issue of road safety management system}

Christian Gerondeau wrote in 2006 year "The great road safety paradox": "Each road-user is responsible for his or her behaviour, but the authorities alone are responsible for the overall level of road crashes", [6]. This short sentence emphasizes the natural "contradiction" in road traffic system. Resolving this conflict, this is a basic aim of any action for construction of road traffic safety management systems; it is currently open problem to research new ideas of coherent methodology and standards. Reasonable seems building a framework for standardizing the process of road transport safety management - based on existing standards for risk management in other areas of techno-social activity. This argument comes from the simple ascertainment: road transport include fragments of several "varieties of safety". Here is about: industrial safety, occupational safety, functional safety, high-risk installations and high-risk processes, Human Factor Risk Management (HFRM). This is because road transport might be interpreted as a complex system, in which structure and work processes, above fragments can be found. It is important to remember about several regularities of psycho-sociological aspects of perception and evaluation of risk - for example the relation of man to risk. For example comparing occupational risk with road traffic risk, keep in mind that the first is "essential risk" (often overrated), and second, may be a "voluntary risk" and thus not appreciated.

As John Adams writes: "risk management is a balancing act," [7]. This statement of quite obvious status quo and may, therefore, is often ignored. The equilibrium in the risk management of any system is a base of any effective action. Disrespect of this fact is the cause of two opposing errors in risk management which results in the increase of social risk aversion and the other undesirable effects. The first mistake is disregard costs of risk reduction, while the second was neglecting social and environmental risk factors.

Road traffic safety management is the process of "which effectively implements road safety policies, including organization, coordination and management of road safety interventions meant to reduce fatalities and injuries in traffic. Successful safety policies are determined by how well an integrated approach is organized; they are essentially a matter of transport safety organization", [6]. Key elements of this process are [8]:

Road Safety Strategy (RSS): "a road safety strategy is a general framework that provides guidance, rationale and direction for actions to be taken (and, at the same time, is shaped by the actions to be taken), based on a clear and broad understanding of the desired road safety objectives". 
Methodological aspects of risk management in road transport

Metodologiczne aspekty zarzadzania ryzykiem $w$ transporcie drogowym

Road Safety Plan, (RSP): “(...) is activity-based and sets out specific actions to be taken, as well as responsibilities and timelines for activity".

Safety Management Plan (SMP): “(...) document that provides project control for the network consultant, identification of safety issues, concerns and deficiencies and prioritising them for investigation, improvement or mitigation with a recognition of the funding requirements (...)".

Safety Management System (SMS): “(...) an arrangement of things/procedures which through skilful application seeks to provide a state of being safe and free from injury, danger and risk when working on or using the public road network".

Starting from 1950 there can be determined four important phases in the development of conceptions, methodologies and practices of road safety management system [9], [10].

Phase 1 - Focus on driver interventions. In the years 1950-1960 safety management was a set of distributed and uncoordinated decisions and actions. Emphasis was placed on the errors of road users, hence any preventive actions focused on educating and training road users, in particular drivers. Such an approach relieve from authorities, part of responsibility for the status of road safety.

Phase 2 - Focus on system-wide interventions. During the 1970-80 appeared a conception of system approach to intervention. Breakthrough in thinking was a epidemiological approach to road accidents interpreted as a sick process. This was a conception of William Haddon, who in his model (later known as the Haddon Matrix) distinguished three process phases of road accident (pre-crash, incrash and post-crash) and proposed interventions in each of them [11]. This resulted in a breakthrough in the study of road safety.

Phase 3 - Focus on system-wide interventions, targeted results and institutional leadership. Starting from 1990 began to use achievements, knowledge and experience of European countries - leaders in the field of action for the improvement of road safety. There was admitted a thesis that increasing motorization level does not have to necessarily mean growth in fatalities, so far will begin planning and investing in improving the quality of road traffic. In the projects of improving road safety, have begun to play an important role such concepts as: objectives prioritizing, determining scopes of competence and responsibility, inter-governmental coordination processes, coordination of resource allocation, mechanisms for financing transport investments, institutional management and other activities for the improvement of road safety, [12], [13].

Phase 4 - Focus on system-wide interventions, long-term elimination of deaths and serious injuries and shared responsibility. In the late 1990s in the Netherlands and Sweden appeared view that the time for revalue of purposes, activities and institutional arrangements in the context of the improvement of road safety. Then had formed great projects and national programs: The Dutch Sustainable Safety [14], [15] and Swedish Vision Zero [16], [17]. 
One of the important assumptions in these projects was the change in approach: improving state of safety is possible, but "road traffic system" has to be adjusted to road users, and not vice versa. It was also approved the need for new approach to: road construction (concept of "forgiving road"), designing of vehicles (the concept of minimizing the effects of collisions for vulnerable road users), development of intelligent systems to assist the driver, development systems of road incidents management, congestion. Saved in these programs the idea of a multi-sectoral approach to safety management of road traffic influence on management strategies in Norway, Finland, Denmark, Switzerland and Australia.

\section{LTSA model of the road safety management system}

Road safety management process should be reviewed in three levels:

1) institutional management functions;

2) interventions;

3) results.

Safety is interpreted as a "product" that is produced starting from level 1 through level 2 and level 3, ultimately [18]. This model was developed for the needs of complex traffic safety management in New Zealand, later was adapted by the European Transport Safety Council [13]. Its usefulness was confirmed in the Sunflower Project [19] and the recommendations of the World Report, [20].

Form this model derived seven institutional management functions, [18], [9]:

1) Results focus.

2) Coordination.

3) Legislation.

4) Funding and resource.

5) Promotion.

6) Monitoring and evaluation.

7) Research and development and knowledge transfer.

These functions are necessary for "production" of interventions, which are second level of model. Interventions take the form of strategies, programs, rules and standards for road safety. They include planning, designing and operating of road infrastructures, vehicles and road users. The main objective of these functions is, in turn, results focus, which in turn is the basis for all the institutional system of road safety. This focus results includes, [9]:

- appraising current road safety performance through high-level strategic review;

- adopting a far-reaching road safety vision or goal for the longer term;

- analysing what could be achieved in the shorter term and proposing targets;

- agreeing targets across the road safety partnership and ensuring stakeholder accountability for results.

This model recommended by the World Bank and the OECD is often presented as 3-level pyramid, Fig. 2. 


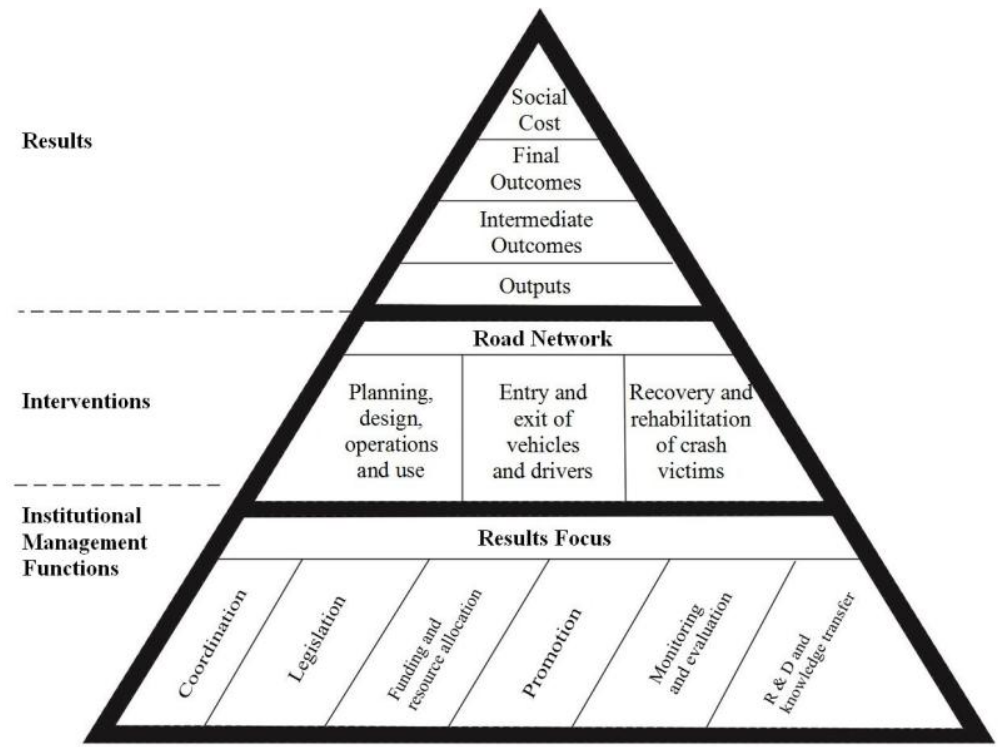

Fig. 2 The road safety management model (LTSA), [9]

\section{A systems approach to road safety management}

In systemic approach road transport is treated as a complex system with any interactions there, sometimes with not known cellular purposes and parameters of main processes of the system. The introduction of this approach to traffic engineering and road safety practices has made in 1968 William Haddon Jr., who in model "3 phases of accident - 3 risk factors" presented the idea of system "safety management of interventions" in road traffic. He inspired by this to further works in this direction. Haddon's model can be today interpreted as a simple variant of the principle of defence-in-depth principle; it remind as well later developed bluntsharp-end model. And no wonder - both of these tools formally describe the essence of the approach to safety. Such a systemic approach to intervention in the field of road accidents is carried out within the framework of a much broader, i.e. road traffic safety management system, [21].

Since 2000 year, when shown how can be used systematic approach to road safety management [18] began to appear global, national and regional variants. In the report of the WHO from 2004 year [21] and the recently developed Auckland Regional Road Safety Plan 2009/12, you can find a description of "new" paradigm for understanding road traffic safety, [22]:

1) Road crash injuries are highly predictable and can be prevented by applying a rational analysis of possible remedial measures.

2) Road safety is a multi-sectoral problem of a public health, and cannot achieve success in the reduction of road accidents, without the full involvement of all objects (among other things, the owners of the risks of road - note A. Sz.) 
3) Any behaviours of road traffic users should not lead to death and injures; traffic safety system should assist them in coping with the ever more intensive conditions.

4) Sensitivity of the human body should be the parameter design for the traffic system and speed management is central.

5) Technology transfer needs to fi t local conditions and local knowledge needs to inform the implementation of local solutions.

6) Injuries in road accidents, can be interpreted as lost capital a social equity issue, therefore, you should strive to equal protection for all road users should be aimed for, since non-motor-vehicle users bear a disproportionate share of road risk.

In Auckland Regional Road Safety Plan (ARRSP) can be found a very current version of systemic approach to road safety management, [22]. Hence a few applications which are worth the publicity:

1) it is necessary the complementarity of roles and activities of the organization at all levels of management and the social groups concerned in achieving the overall aim, namely to retain a minimum possible risk of road accidents in a given area;

2) road authorities, city planners, investors must make efforts in planning, designing and building a sustainable and increasingly safe transport;

3) the necessary activities are, inter alia:

a) increase safe access to all types of transport;

b) build " forgiving " transport infrastructure (road);

c) admit that the management of speed of vehicles is a central element of this approach.

\section{Intersectoral organisation of road safety.}

Systemic approach and close to it integrated road safety management can be also fund in intersectional conception of structure of road traffic safety management. Key objects of such structure of management should be from public sector as well as from private sector. Introducing a principle of "multi-sectoral" in practise means deep organizational changes, difficult to launch. Below there is a draft of ,intersectoral organisation of road safety”, [23]. The main thesis is: „Road traffic accidents and injuries are the effect of multi-factorial processes, so road safety management needs to be intersectoral". One of proposition is 10-sectoral organisation of road safety: 1. Urban planning; 2. Transport, traffic; 3. Roads; 4. Laws, Justice; 5. Enforcement; 6. Public Health; 7. Education and training; 8. Communication 9. Research; 10. Industry and trade. Each of sector generate its problems in context of safety management, [23]. 
Methodological aspects of risk management in road transport

Metodologiczne aspekty zarzadzania ryzykiem $w$ transporcie drogowym

\section{Safe and sustainable traffic system}

One of the great objectives of modern European transport policy is striving to implement sustainable road safety, [13]. The recommended approach for achieving this aim is a systemic approach, [24]. The first major step in the realisation of this objective was developed by the Institute for Road Safety Research and the Dutch Ministry of Transport, and developed in cooperation with local authorities, a threeyear programme on "sustainable safety" [14], [21]. But the conception of sustainable road safety appeared in the Netherlands at the beginning of 1990, [25]. The issue was a structural changes in the system of road traffic, which have referred to actively expanded in the world of conception sustainable development. In this conception pointed on a proactive and systemic actions for the improvement of the status of traffic safety, which ensured that maintenance (behavior) of the state of safety in time. In the conception of sustainable development of road safety stressed a latent errors in the system of road traffic, so called systemic, which could result in accidents. Issue relates also that efforts to improve road safety, should not as much become dependent on individual decisions of road users, but indicate the elements which are responsible for designing and functioning of road traffic system. There are also specified five principles of sustainable safety [13]:

1) Functionality of roads. Monofunctionality of roads as either through roads, distributor roads, or access roads, in a hierarchically structured road network.

2) Homogeneity of mass and/or speed and direction. Equality in speed, direction, and mass at and direction medium and high speeds.

3) Predictability of road course and road user behaviour by a recognizable road design. Road environment and road user behaviour that support road user expectations through consistency and continuity in road design.

4) Forgivingness of the environment and of road users. Injury limitation through a forgiving road environment and anticipation of road user behaviour.

5) State awareness by the road user. Ability to assess one's task capability to handle the driving task.

These principles have been the foundation for working up in Holland system of road traffic safety management - in accordance with the conception - "sustainable safety".

\section{Conclusions}

Status quo of knowledge and practice from a range of risk management in road transport can be characterized as follows: in spite of the existing special methodologies, best practices guides, science and engineering studies in many countries of the world - there is no consistent methodology and, consequently, international risk management standards in road transport. However, it should be recalled that for many years are made attempts in this regard. 
Their effects are developed tools to support decision-making in different sectors and at different levels of the management of road transport, inter alia: (1) road infrastructure management automation; (2) management of road traffic (incident management, congestion management); (3) management of the carriage of hazardous materials; (4) management of transport operations; (5) management of working risks in transport organizations; (6) manage the travel of individual participants of road traffic (driving models, risk maps).

Regulations within the European Union have received two spectacular systems: risk management in tunnels (Directive 2004/54/EU) and the management of road infrastructure risk, (Directive 2008/96/EU). In both solutions clearly used from general methodology of risk management.

A very important problem is the integration of risk management methods in all modes of transport, as well as on their "contact". In Poland recently completed ZEUS project has taken up it, [26], [27].

Today the basic challenge for scientists, engineers and transport policy makers is to create a methodological framework and develop a universal standard for integrated management of transport safety. You must remember, however, that from the point of safety management, there are important differences between different modes of transport.

\section{References}

[1] Szymanek A., Teoria i metodologia zarządzania ryzykiem w ruchu drogowym. Wyd. Politechniki Radomskiej, Radom 2012; ISBN 978-83-7351505-5

[2] AS/NZS 4360. (2004). Standards Australia SAA/NZS HB 143: 2004, Guidelines for managing risk in the Australian and New Zealand public sector

[3] ISO 73 (2001). Risk Management-Vocabulary-Guidelines for Use in Standards, Draft ISO Guide 73, 2001

[4] Szymanek A., Rozwój standardów zarządzania ryzykiem w transporcie drogowym. Logistyka 3/2014, CD1 - s. 6185 - 6191

[5] ISO 39001 (2012): Road traffic safety (RTS) management systems Requirements with guidance for use

[6] Abouraad S., Elsenaar P., Road Safety Management in ESCWA Countries Critical Issues in Implementation, In: ESCWA-WHO Regional Conference Global Road Safety Partnership, Cairo, 20-21 December 2006. Available from <http://www.grsproadsafety.org>

[7] Adams J., Complexity \& Uncertainty in a Risk Averse Society. Three Framing Devices for Managing Risk, In: For Omega Conference, London, 22 January 2007. Available from <http://john-adams.co.uk> 
Methodological aspects of risk management in road transport

Metodologiczne aspekty zarzadzania ryzykiem $w$ transporcie drogowym

[8] Guidelines for developing and implementing a safety management system for road controlling authorities. Land Transport Safety Authority, New Zealand, November 2005. Available from http://www.ltsa.govt.nz)

[9] Bliss T. \& Breen J., Implementing the Recommendations of the World Report on Road Traffic Injury Prevention. Country Guidelines for the Conduct of Road Safety Management Capacity Reviews and the Specifi cation of Lead Agency Reforms, Investment Strategies and Safe System Projects. The World Bank Global Road Safety Facility, 2009; <http://siteresources.worldbank.org>

[10] Szymanek A., Ewolucja podejść badawczych do systemu zarządzania bezpieczeństwem drogowym. Logistyka 6/2014, CD - s. 10497 - 10502

[11] Haddon W. Jr., The changing approach to the epidemiology, prevention, and amelioration of trauma: The transition to approaches etiologically rather than descriptively based. American Journal of Public Health, 1968, 58, pp. 1431-1438

[12] Road safety is No accident; brochure for World health day 2004, quoted as: Harry M., Derriks H.M \& Mak P.M., IRTAD Special Report Underreporting of Road Traffic Casualties. The Netherlands, June 2007. Available from $<$ http://www.oecd.org/>

[13] Wegman F. \& Aarts L. (Eds.), Advancing Sustainable Safety. National Road Safety Outlook for 2005-2020. SWOV Institute for Road Safety Research. SWOV, Leidschendam, 2006; tab.1.3, p. 39, ISBN-10: 90-807958-7-9

[14] Wegman F. \& Elsenaar P., Sustainable solutions to improve road safety in the Netherlands. Leidschendam. Institute for Road Safety Research, SWOV Report D-97-8, 1997

[15] Wegman F., Advancing Sustainable Safety in the Netherlands. SWOV Institute for Road Safety Research The Netherlands, September 2008. Available from <http://www.swov.nl>

[16] Tingvall C., The Zero Vision, In: Transportation, traffic safety and health: the new mobility, van Holst, H.; Nygren, A. \& Thord, R. (eds.). Proceedings of the 1st International Conference, Gothenburg, Springer-Verlag, 1995, pp. 35-57

[17] Tingvall C. \& Haworth N., Vision Zero; An ethical approach to safety and mobility. In: Proceedings of the 6th ITE International Conference Road Safety and Traffic Enforcement; Beyond 2000, Melbourne, September 6-7, 1999

[18] Land Transport Safety Authority. Road Safety Strategy 2010: A Consultation Document. National Road Safety Committee, Land Transport Safety Authority, Wellington, 2000

[19] Koornstra M.J. et al., SUNflower: a comparative study of the development of road safety in Sweden, the United Kingdom, and the Netherlands. SWOV, 
Leidschendam, 2002. Available from <http://ec.europa.eu/transport/roadsafety _library/publications/sunflower_report>

[20] Bliss T., Implementing the Recommendations of The World Report on Road Traffic Injury Prevention. Transport Note No. TN-1, The World Bank, Washington DC, 2004

[21] World report on road traffic injury prevention, Peden M. et al. (eds.), World Health Organization 2004, ISBN 924156260 9. Available from <http://whqlibdoc.who.int/publications/2004/9241562609.pdf>

[22] Road Safety Strategy 2011-20. Australian Capital Territory, Canberra, 2011; ISBN 0-642-60406-1)

[23] Muhlrad N., Road safety and other policies: conflict or integration? 19th ICTCT Workshop Proceedings, Mińsk 2006. Available from $<$ www.ictct.org>

[24] PIARC Lexicon on Road and Traffic Engineering, validated by the members of the Technical and Terminology Committees of PIARC. December 2006. Available from <http://termino.piarc.org >

[25] Koornstra M. J., The evolution of road safety and mobility. IATSS (International Association of Traffic and Safety Sciences), Research, 1992, Vol.16, No. 2, pp. 129-148

[26] Zintegrowany system bezpieczeństwa transportu, tomy 1-3, red. R. Krystek, WKŁ, Warszawa-Gdańsk, 2009-2010

[27] Szymanek A., Integracja metod analizy ryzyka. (W:) Zintegrowany system bezpieczeństwa transportu, Krystek, R. (ed.), vol. 2, pp. 294-295, WKŁ, Warszawa, 2009; ISBN 978-83-206-1742-9

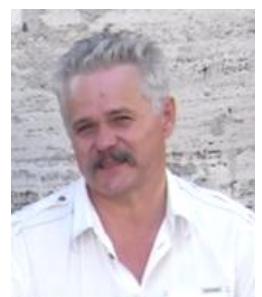

Andrzej Szymanek PhD, DSc, Eng. A graduate of AGH Cracow, where he graduated from the Fundamental Problems of Technology with a specialization in applied mathematics. Doctorate at the Gdansk University of Technology in the Department of Highway Engineering. Habilitation in the field of transport at his alma mater - the University of Technology and Humanities in Radom (Faculty of Transport and Electrical Engineering). His research interests relate to two thematic areas: 1. safety management systems, road transport, 2. mathematical modeling of the safety and risks in technical systems. He is the author of two books, several chapters and over 100 articles and research papers published at home and abroad, as well as many unpublished studies. 
Methodological aspects of risk management in road transport Metodologiczne aspekty zarzadzania ryzykiem $w$ transporcie drogowym 